\title{
Chemical synthesis of peptidoglycan mimetic - disaccharide- tetrapeptide conjugate and its hydrolysis by bacteriophage T5, RB43 and RB49 L-alanyl-D-glutamate peptidases
}

\author{
Viatcheslav Azev ${ }^{1}$, Alexey Chulin ${ }^{1}$, Maxim Molchanov ${ }^{2}$, Dmitry Prokhorov ${ }^{2}$, Galina Mikoulinskaia ${ }^{1}$, Vladimir N \\ Uversky ${ }^{\text {Corresp., 3, } 4 \text {, Viktor Kutyshenko }}{ }^{\text {Corresp. } 2}$ \\ ${ }^{1}$ Branch of Shemyakin and Ovchinnikov's Institute of Bioorganic Chemistry, Russian Academy of Sciences, Pushchino, Moscow Region, Russia \\ 2 Institute for Theoretical and Experimental Biophysics, Russian Academy of Sciences, Pushchino, Moscow Region, Russia \\ 3 Laboratory of New Methods in Biology, Institute for Biological Instrumentation of the Russian Academy of Sciences, Federal Research Center "Pushchino \\ Scientific Center for Biological Research of the Russian Academy of Sciences", Pushchino, Moscow Region, Russia \\ 4 Department of Molecular Medicine and USF Health Byrd Alzheimer's Research Institute, Morsani College of Medicine, University of South Florida, Tampa, \\ Florida, United States \\ Corresponding Authors: Vladimir N Uversky, Viktor Kutyshenko \\ Email address: vuversky@usf.edu, kutyshenko@rambler.ru
}

Background. Endolysins of a number of bacteriophages, including coliphages T5, RB43, and RB49, target the peptidoglycans of the bacterial cell wall. The backbone of these bacterial peptidoglycans consist of alternating $\mathrm{N}$-acetylglucosamine and $\mathrm{N}$-acetylmuramic acid residues that is further "reinforced" by the peptide subunits. Because of the mesh-like structure and insolubility of peptidoglycans, the processes of the peptidoglycan binding and hydrolysis by enzymes cannot be studied by spectral methods. To overcome these issues we synthesized and analyzed here one of the simplest water soluble peptidoglycan mimetics.

Methods. A compound has been synthesized that mimics the peptidoglycan fragment of the bacterial cell wall, N-acetylglucosaminyl- $\beta$ (1-4)-N-acetylmuramoyl-I-alanyl- - -d-glutamyl-I-alanyl-d-alanine. NMR was used to study the degradation of this peptidoglycan mimetic by lytic l-alanoyl-d-glutamate peptidases of colibacteriophages T5, RB43, and RB49 (EndoT5, EndoRB43, and EndoRB49, respectively).

Results. The resulting glycopeptide mimetic was shown to interact with the studied enzymes. Its hydrolysis occurred through the bond between I-Ala and d-Glu. This artificial substrate mimetic was hydrolyzed by enzymes at different rates, which decreased outside the $\mathrm{pH}$ optimum. The EndoT5 demonstrated the lowest hydrolysis rate, whereas the EndoRB49-driven hydrolysis was the fastest one, and EndoRB43 displayed an intermediate potency. These observations are consistent with the hypothesis that EndoRB49 is characterized by the lowest selectivity, and hence the potentially broader spectrum of the peptidoglycan types subjected to hydrolysis, which was put forward in the previous study (Shadrin et al. 2020). We also show that to hydrolyze this glycopeptide mimetic, enzymes approach the glycopeptide near the methyl groups of all three alanines. 


\section{Chemical Synthesis of Peptidoglycan Mimetic -}

3 Disaccharide-Tetrapeptide Conjugate and its

4 Hydrolysis by Bacteriophage T5, RB43 and RB49 L-

5 Alanyl-D-Glutamate Peptidases

6

7

Viatcheslav N. Azev, ${ }^{1}$ Alexey N. Chulin, ${ }^{1}$ Maxim V. Molchanov, ${ }^{2}$ Dmitry A. Prokhorov, ${ }^{2}$ Galina V. Mikoulinskaia, ${ }^{1}$ Vladimir N. Uversky, ${ }^{3,4,{ }^{*}}$ and Viktor P. Kutyshenko ${ }^{2,{ }^{*}}$

${ }^{1}$ Branch of Shemyakin and Ovchinnikov's Institute of Bioorganic Chemistry, Russian Academy of Sciences, Science avenue, 6, Pushchino, Moscow Region, Russia, 142290.

2 Institute for Theoretical and Experimental Biophysics, Russian Academy of Sciences, Institutskaya str., 3, Pushchino, Moscow region, Russia, 142290.

${ }^{3}$ Laboratory of New Methods in Biology, Institute for Biological Instrumentation of the Russian Academy of Sciences, Federal Research Center "Pushchino Scientific Center for Biological Research of the Russian Academy of Sciences", Pushchino, Moscow region 142290, Russia ${ }^{4}$ Department of Molecular Medicine and USF Health Byrd Alzheimer's Research Institute, Morsani College of Medicine, University of South Florida, Tampa, FL, USA

Corresponding Author:

VPK, Institute for Theoretical and Experimental Biophysics, Russian Academy of Sciences, Institutskaya str., 3, Pushchino, Moscow region, Russia, 142290Phone: +7 (4967) 73-92-26; Fax: +7 (4967) 33-05-53; VNU, Department of Molecular Medicine and USF Health Byrd Alzheimer's Research Institute, Morsani College of Medicine, University of South Florida, Tampa, FL, USA Phone: 813-974-5816; Fax: 813-974-7357; Email address: kutyshenko@,rambler.ru (VPK); vuversky@usf.edu (VNU)

\section{Abstract}

Background. Endolysins of a number of bacteriophages, including coliphages T5, RB43, and RB49, target the peptidoglycans of the bacterial cell wall. The backbone of these bacterial peptidoglycans consist of alternating $\mathrm{N}$-acetylglucosamine and $\mathrm{N}$-acetylmuramic acid residues that is further "reinforced" by the peptide subunits. Because of the mesh-like structure and insolubility of peptidoglycans, the processes of the peptidoglycan binding and hydrolysis by enzymes cannot be studied by spectral methods. To overcome these issues we synthesized and analyzed here one of the simplest water soluble peptidoglycan mimetics.

Methods. A compound has been synthesized that mimics the peptidoglycan fragment of the bacterial cell wall, $\mathrm{N}$-acetylglucosaminyl- $\beta(1-4)-\mathrm{N}$-acetylmuramoyl-L-alanyl- $\gamma$-D-glutamyl-L- 
alanyl-D-alanine. NMR was used to study the degradation of this peptidoglycan mimetic by lytic L-alanoyl-D-glutamate peptidases of colibacteriophages T5, RB43, and RB49 (EndoT5, EndoRB43, and EndoRB49, respectively).

Results. The resulting glycopeptide mimetic was shown to interact with the studied enzymes. Its hydrolysis occurred through the bond between L-Ala and D-Glu. This artificial substrate mimetic was hydrolyzed by enzymes at different rates, which decreased outside the $\mathrm{pH}$ optimum. The EndoT5 demonstrated the lowest hydrolysis rate, whereas the EndoRB49-driven hydrolysis was the fastest one, and EndoRB43 displayed an intermediate potency. These observations are consistent with the hypothesis that EndoRB49 is characterized by the lowest selectivity, and hence the potentially broader spectrum of the peptidoglycan types subjected to hydrolysis, which was put forward in the previous study (Shadrin et al. J Appl Microbiol. 2020. doi: 10.1111/jam.14910). We also show that to hydrolyze this glycopeptide mimetic, enzymes approach the glycopeptide near the methyl groups of all three alanines.

\section{Introduction}

For the release of phage progeny from host bacterial cell, lytic bacteriophages induce the synthesis of enzymes capable of degrading peptidoglycan of the bacterial cell wall either by hydrolysis of the peptide or glycosidic bonds, or by the non-hydrolytic rupture of the latter (Young 2014). Bacterial peptidoglycan is a complex polymeric structure. It has a carbohydrate backbone consisting of alternating $\mathrm{N}$-acetylglucosamine and $\mathrm{N}$-acetylmuramic acid residues linked by $\beta(1-4)$ glycosidic bonds that is further "reinforced" by the peptide subunits, often linked by interpeptide bridges. The stem peptide is linked to the muramic acid residue by an amide bond. The composition of the peptide subunit, as well as the structure of peptide bridges, vary, and these variations underlie the classification of peptidoglycans (Schleifer \& Kandler 1972). Types A and B differ in the branching position (from third amino acid residue of one stem peptide to fourth of the other, or from second to fourth, respectively) and the amino acid at the N-terminus of the stem peptide (for type A peptidoglycan, this is L-Ala). Next in the nomenclature is a number that reflects the structure of the bridge (for example, 1 corresponds to direct cross-linking between peptides stems, with no bridging amino acids). Finally, the Greek letter in the nomenclature reflects the type of amino acid at position 3 (e.g., $\gamma$-diaminopimelic acid, DAP). The amino acid at position 3 is characterized by the greatest variability: L-Lys, LOrn, DAP are often found, less often meso-Lanthionine, L-5-Hydroxylysine, L-Ala, L-Glu, and others are found (Vollmer et al. 2008). In peptidoglycans of type A, which are characteristic of most Gram-positive and all Gram-negative bacteria, the L-Ala-D-Glu bond is always present. This bond is the target of endolysins of a number of bacteriophages, including coliphages $\mathrm{T} 5$, RB43, and RB49 (Mikoulinskaia et al. 2018; Mikoulinskaia et al. 2013). Structural methods (most often solid-state NMR) are used to study peptidoglycans and their structures (Bougault et al. 2019; Kern et al. 2008). Structural studies of enzymes for which peptidoglycan is a substrate are more complicated. To analyze the binding and hydrolysis of such a complex substrate by enzymes, usually soluble peptidoglycan (PG) fragments obtained as a 
79 result of partial hydrolysis by other enzymes (for example, muramidase or lysostaphin) are used

80 (Maya-Martinez et al. 2018). However, the hydrolysates obtained in this way are difficult to

81 standardize. Unconditional unification is achieved by using synthetic compounds that mimic a

82 natural substrate, and such studies are known primarily for enzymes of Gram-positive bacteria

83 (Lee et al. 2019; Perez-Dorado et al. 2007). In this case, both disaccharide dipeptides (muramyl

84 dipeptides (MDPs) or glucosaminylmuramyl dipeptides (GMDPs)) and larger molecules are

85 used.

86 The natural diversity of amino acids in position 3 of the PG peptide subunit led us to the idea of

87 creating a mimetic that does not completely repeat the structure of natural peptidoglycan, but

88 mimics its fragment as much as possible. This mimetic can be used to study the mechanism of

89 binding and hydrolysis of peptidoglycan by L-alanyl-D-glutamate peptidases, which have high

90 specific activity on the natural substrate. The carbohydrate moiety in such a mimetic should have

91 been represented by a minimal disaccharide. The peptide is naturally long: it consists of four

92 amino acids, the last of which is D-alanine. The choice of one more L-alanine in the 3 position of

93 the peptide is due to the following considerations. First, a study of the interaction of the long-

94 known peptidoglycan mimetic GMDP with our enzymes showed that this compound is weakly

95 fixed by the protein in the L-alanine region, but hydrolysis of the peptide bond does not occur. In

96 peptidoglycan of the type A $1 \gamma$ in the 3 position after L-Ala-D-Glu there is meso-diaminopimelic

97 acid (DAP), which contains a rather extended hydrophobic region - $\left(\mathrm{CH}_{2}\right)_{3}$, followed by D-

98 alanine. We hypothesized that hydrophobic interactions play an important role in peptide binding

99 and, possibly, it is their number that is lacking in GMDP. A bridging of two alanines was chosen

100 to provide sufficient hydrophobicity and ease of identification by NMR. The entire construction

101 of the disaccharide-tetrapeptide as a whole was designed as a basic one, in which it is planned to

102 introduce further directed variations to simulate experiments aimed at studying various

103 enzymatic properties (reaction rate, processivity, affinity for the substrate).

104 In short, it is impossible to study the process of the substrate binding and hydrolysis by enzymes

105 by spectral methods, which provide detailed structural information, since natural peptidoglycans

106 are insoluble. In this work, an attempt was made to circumvent these limitations by synthesizing

107 one of the simplest water soluble peptidoglycan mimetics and to use this compound to study the

108 process of its hydrolysis in vitro by recombinant L-alanyl-D-glutamate peptidases of

109 bacteriophages T5, RB43, and RB49 (EndoT5, EndoRB43, and EndoRB49).

110

111 Materials \& Methods

112 All solvents (except HPLC grade acetonitrile), N-methylmorpholine, pyridine, trifluoroacetic

113 acid were purified before the use according to the standard procedures (Armarego \& Chai 2012).

114 Dimethylformamide, N-methylmorpholine, and pyridine were kept over 4 A molecular sieves

115 after purification. Dichloromethane was kept over barium oxide. d6-DMSO and $\mathrm{D}_{2} \mathrm{O}$ were

116 supplied by Cambridge Isotope Laboratories (USA). N-Acetylglucosaminyl- $\beta(1-4)-\mathrm{N}-$

117 acetylmuramic acid was a generous gift of Dr. Vasiliy N. Stepanenko (Experimental 
118 Biotechnological Manufacture, IBCh RAS). Bis(pentafluorophenyl) carbonate was prepared as 119 described elsewhere (Medvedkin et al. 1989).

120 TLC was performed on Merck F254 silica gel G plates (part 1.05554.0001). Spots were detected

121

122

123

124

125

126

127

128

129

130

131

132

133

134

135

136

137

138

139

140

141

142

143

144

145

146

147

148

149

150

151

152

153

154

155

156 by 1) dipping the eluted plates into the ninhydrin solution (ninhydrin $0.5 \mathrm{~g}$, butanol-1 $250 \mathrm{~mL}$, acetic acid $50 \mathrm{~mL}$, sym-collidine $10 \mathrm{~mL}$ ) followed by heating with a heat-gun; 2) dipping the eluted plates into the phosphomolybdic acid solution (phosphomolybdic acid $6 \mathrm{~g}$, ethanol $70 \mathrm{~mL}$ ) followed by heating with a heat-gun.

NMR spectra were acquired on Bruker AVANCE III spectrometer (Bruker BioSpin, Germany) $\left({ }^{1} \mathrm{H}\right.$ at $600 \mathrm{MHz},{ }^{13} \mathrm{C}$ at $\left.125 \mathrm{MHz}\right)$ and were referenced to a residual solvent signals. Unless otherwise stated, the spectra were taken at sample concentrations $c a .7-14 \mathrm{mg} / \mathrm{mL}$ in standard 5 mm NMR ampules using standard pulse sequences. Peak positions are reported in ppm, coupling constants are reported in Hertz (Hz). High-resolution mass-spectra were acquired on Orbitrap Elite Hybrid Ion Trap-Orbitrap Mass Spectrometer.

HPLC monitoring was accomplished on an instrument equipped with Waters 1525 binary HPLC pump and Waters 2487 Dual $\lambda$ Absorbance Detector using a Phenomenex Synergi Hydro-RP $\mathrm{C} 18$ column $(0.46 \mathrm{~cm} \times 25 \mathrm{~cm})$ and UV detection at $226 \mathrm{~nm}$ eluting at $1 \mathrm{~mL} \mathrm{~min}^{-1}$. Solvent A: water (0.1\% TFA), solvent B: acetonitrile. Gradient 1: 0-1 min: 0\% B; 1-20 min: 0-55\% B; 2021 min: 55-0\% B; 21-25 min: 0\% B. Gradient 2: 0-2 min: 3\% B; 2-18 min: 3-50\% B; $18-19$ min: 50-3\% B; 19-25 min: 3\% B.

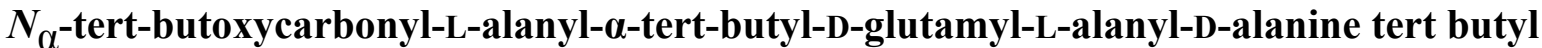

ester (4). Compound 2 (570 mg, $1.5 \mathrm{mmol})$ was dissolved in DCM (10 mL) with stirring in 25 $\mathrm{mL}$ round bottom flask. Pentafluorophenyl trifluoroacetate $(345 \mu \mathrm{L}, 2 \mathrm{mmol})$ and pyridine $(175$ $\mu \mathrm{L}, 2.2 \mathrm{mmol}$ ) were successively added to the substrate solution, the flask was tightly closed with a glass stopper and the reaction mixture was stirred overnight. The reaction mixture was diluted with DCM $(20 \mathrm{~mL})$ and the resulting solution was successively washed with $0.1 \mathrm{M}$ aqueous $\mathrm{NaHCO}_{3}(15 \mathrm{~mL}), 0.1 \mathrm{M}$ aqueous $\mathrm{HCl}(15 \mathrm{~mL})$ and water $(20 \mathrm{~mL})$. The organic layer was dried with $\mathrm{MgSO}_{4}$ and evaporated. The resulting oily product was dissolved in ethyl acetate $(2 \mathrm{~mL}$ ) and the solution was slowly diluted with hexane (up to $15 \mathrm{~mL}$ ). The precipitated activated ester was filtered off, washed with hexane $(210 \mathrm{~mL})$ and dried in dessicator over phosphorus pentoxide and paraffin to provide $412 \mathrm{mg}$ of white solid that was homogeneous by TLC $\left(\mathrm{R}_{\mathrm{f}}=0.54\right.$, silica gel, 1:1 v/v EtOAc/n-heptane $)$.

A part of the solid obtained (362 mg, $0.67 \mathrm{mmol}$ ) was dissolved in $\mathrm{MeCN}$ (5 ml) with stirring. Compound 3 (185 mg, $0.67 \mathrm{mmol}$ ) followed by NMM (150 $\mu \mathrm{L}, 1.34 \mathrm{mmol})$ were added to the solution. The reaction mixture was stirred at $\mathrm{rt}$ and in $c a .10$ minutes precipitate formation was observed. DCM (10 mL) was added to the suspension and the reaction mixture was stirred overnight. The reaction mixture was filtered, the solid material on the filter was rinsed with DCM $(3.2 \mathrm{~mL})$, the filtrates were combined and evaporated in vacuo. EtOAc $(25 \mathrm{~mL})$ followed by water $(25 \mathrm{ml})$ were added to the residue obtained. The aqueous layer was separated and the 
157 organic layer was washed with $0.1 \mathrm{M}$ aqueous $\mathrm{NaHCO}_{3}(10 \mathrm{~mL}), 0.1 \mathrm{M}$ aqueous $\mathrm{HCl}(10 \mathrm{~mL})$

158

159

160

161

162

163

164

165

166

167

168

169

170

171

172

173

174

175

176

177

178

179

180

181

182

183

184

185

186

187

188

189

190

191

192

193 and water $(20 \mathrm{~mL})$. The organic layer was dried with $\mathrm{Na}_{2} \mathrm{SO}_{4}$, filtered and evaporated. Ether (10 $\mathrm{mL}$ ) was added to the oily residue and the reaction product solidified. The solid obtained was filtered, washed with ether $(25 \mathrm{~mL})$ and dried in vacuo overnight to provide 4 (239 $\mathrm{mg}, 62 \%)$. For compound 4: m.p. 175-176; $\mathrm{R}_{\mathrm{f}}=0.16$ (silica gel, 9:1 v/v $\mathrm{CHCl}_{3} / \mathrm{MeOH}$ ), $\mathrm{R}_{\mathrm{f}}=0.74$ (silica gel, 8:1:1 v/v/v MeCN/CHCl $3 / \mathrm{AcOH}$ ); ${ }^{1} \mathrm{H}$ NMR (DMSO-d6) $\delta$ 1.14-1.21 (m, 6H, $\mathrm{CH}_{3}$-Ala), 1.23 (d, $J=7.32 \mathrm{~Hz}, 3 \mathrm{H}, \mathrm{CH}_{3}$-D-Ala), 1.29-1.46 (m, 27H, Boc, 2tBu), 1.69-1.82 (m, 1H, CHßGlu), 1.87-1.98 (m, 1H, CHßGlu), 2.14 ( $\psi \mathrm{t}, J=7.97 \mathrm{~Hz}, 2 \mathrm{H}, \mathrm{CH} \gamma \mathrm{Glu}$ ), 3.83-4.15 (m, 3H, CH $\alpha$-D-Ala, CH $\alpha$-Ala, CHaGlu), 4.29 (dq, $J=7.09,7.53 \mathrm{~Hz}, 1 \mathrm{H}, \mathrm{CH} \alpha-\mathrm{Ala}$ ), 6.82 (d, $J=7.27 \mathrm{~Hz}, 1 \mathrm{H}$, NHBoc), 7.96 (d, $J=7.53 \mathrm{~Hz}, 1 \mathrm{H}$, NHAla), 8.02 (d, $J=7.99 \mathrm{~Hz}, 1 \mathrm{H}, \mathrm{NH}-\mathrm{D}-\mathrm{Glu}), 8.10$ (d, $J=$ $7.31 \mathrm{~Hz}, 1 \mathrm{H}, \mathrm{NH}-\mathrm{D}-\mathrm{Ala}) ;{ }^{13} \mathrm{C}$ NMR $\delta 172.82,172.08,171.56,170.90,170.81,154.94,80.58$, $80.29,78.03,52.14,49.63,48.23,47.94,31.31,28.14,27.56,27.11,18.36,18.30,17.01$; HRMS (+ESI) $m / z$ for $\mathrm{C}_{27} \mathrm{H}_{49} \mathrm{~N}_{4} \mathrm{O}_{9}[\mathrm{M}+\mathrm{H}]^{+}$calculated 573.3494, observed: 573.3499 .

L-alanyl- $\gamma$-D-glutamyl-L-alanyl-D-alanine trifluoroacetate (5). Compound 4 (239 mg, 0.41 mmol) was dissolved in a mixture of trifluoroacetic acid and water $(95: 5 \mathrm{v} / \mathrm{v}, 4 \mathrm{~mL})$ with stirring. The reaction mixture was kept at 20 for 60 minutes and evaporated. Ether $(7 \mathrm{~mL})$ was added to the evaporation residue and the solid material obtained was separated from the ether mother liquor using centrifuge. The solid was resuspended and centrifuged in ether $(3 \times 1.5 \mathrm{ml})$ before it was dried in vacuo to provide 5 (181 $\mathrm{mg}, 92 \%)$ that was used directly in the next step without further purification. For compound 5: m.p. 139-140; $\mathrm{R}_{\mathrm{f}}=0.6$ (silica gel, 15:9:1:2 v/v/v/v $\mathrm{CHCl}_{3} / \mathrm{MeOH} / \mathrm{AcOH} / \mathrm{H}_{2} \mathrm{O}$ ); Retention time (Gradient 1): $8.98 \mathrm{~min}$; HRMS (+ESI) $\mathrm{m} / \mathrm{z}$ for $\mathrm{C}_{14} \mathrm{H}_{25} \mathrm{~N}_{4} \mathrm{O}_{7}[\mathrm{M}+\mathrm{H}]^{+}$calculated 361.1718, observed: 361.1709 .

\section{$\mathrm{N}$-acetylglucosaminyl- $\beta(1-4)-\mathrm{N}$-acetylmuramoyl-L-alanyl- $\boldsymbol{\gamma}$-D-glutamyl-L-alanyl-D-alanine}

(1). Disaccharide 6 (149 mg, $0.3 \mathrm{mmol})$ was dissolved in DMF $(1 \mathrm{~mL})$ with stirring under argon. N-Methylmorpholine ( $33 \mu \mathrm{L}, 0.3 \mathrm{mmol}$ ) followed by bis(pentafluorophenyl) carbonate (118 $\mathrm{mg}$, $0.3 \mathrm{mmol}$ ) were successively added to the solution of disaccharide and the reaction mixture was stirred at ambient temperature under argon. The reaction was complete in $1 \mathrm{~h}$ as indicated by the disappearance of 6 (TLC: silica gel, 2.5:2.2:0.2:0.25 v/v/v/v CHCl $3 / \mathrm{MeOH} / \mathrm{AcOH} / \mathrm{H}_{2} \mathrm{O}$, staining with phosphomolybdic acid; for $\mathbf{6}$ : $\mathrm{R}_{\mathrm{f}}=0.5$, for (presumable) pentafluorophenyl ester of $\mathbf{6}$ :

$\left.\mathrm{R}_{\mathrm{f}}=0.65\right)$. Pyridine ( $\left.30 \mu \mathrm{L}, 0.375 \mathrm{mmol}\right)$ followed by tetrapeptide $5(119 \mathrm{mg}, 0.25 \mathrm{mmol})$ were

added to the reaction mixture with stirring. After the complete dissolution of 5 stirring was turned off and the reaction was allowed to proceed for $16 \mathrm{~h}$. The reaction mixture was added dropwise to ethyl acetate $(40 \mathrm{~mL})$ and the suspension was centrifuged. The solid was resuspended and centrifuged in EtOAc $(3 \times 10 \mathrm{~mL}), \mathrm{MeCN}(3 \times 10 \mathrm{~mL})$, ether $(3 \times 10 \mathrm{~mL})$. The remaining solid was dried in vacuo to provide $210 \mathrm{mg}$ of crude product. Compound 1 (46 mg, 22 
194

195

196

197

198

199

200

201

202

203

204

205

206

207

208

209

210

211

212

213

214

215

216

217

218

219

220

221

222

223

224

225

226

227

228

229

230

231

232

233

\%) was isolated using RP-HPLC (2.1 x $25 \mathrm{~cm} \mathrm{C} 18$ column, isocratic elution with $6 \% \mathrm{MeCN}$ in water (0.1\% TFA)). For compound 1: Retention time (Gradient 2): $9.47 \mathrm{~min}$ (isomer 1), 9.77 min (isomer 2); HRMS (+ESI) $m / z$ for $\mathrm{C}_{33} \mathrm{H}_{54} \mathrm{~N}_{6} \mathrm{O}_{19}[\mathrm{M}+\mathrm{H}]^{+}$calculated 839.3517, observed: 839.3488 .

Recombinant L-alanoyl-D-glutamate peptidases of colibacteriophages T5, RB43, and RB49. Active homogeneous preparations of the recombinant enzymes EndoT5, EndoRB43 and EndoRB49) were obtained from producer strains obtained earlier, using the previously developed method (Mikoulinskaia et al. 2018) and stored frozen at $-20^{\circ} \mathrm{C}$.

NMR-based analysis of the GMTP degradation. NMR measurements were conducted on the AVANCE $600 \mathrm{III}$ spectrometer (Bruker), with an operating frequency of $600 \mathrm{MHz}$, at $298 \mathrm{~K}$, a spectral width of $24 \mathrm{ppm}$ and the 90 -degree pulse of $11 \mu \mathrm{s}$, number of scans $32-128$, depending on the value of the signals required for the processing. NOE spectra in the spin diffusion mode were excited at a frequency of the methyl pool of the protein $\sim 0.8 \mathrm{ppm}$. To excite the effect, we used power $65-70 \mathrm{db}$, relaxation delay $3 \mathrm{sec}$, excitation time $0.5 \mathrm{sec}$, mixing time $0.08 \mathrm{sec}$, number of accumulations 1000-4000. To assign lines in the spectrum of the glycopeptide, twodimensional experiments were carried out: ${ }^{1} \mathrm{H}-{ }^{13} \mathrm{C}-\mathrm{HSQC},{ }^{1} \mathrm{H}-{ }^{13} \mathrm{C}-\mathrm{HMBC},{ }^{1} \mathrm{H}-{ }^{1} \mathrm{H}-\mathrm{COSY},{ }^{1} \mathrm{H}-{ }^{1} \mathrm{H}-$ TOCSY with standard pulse sequences of the Bruker library.

GMTP was dissolved in Tris- $\mathrm{HCl}$ buffer $(50 \mathrm{mM}, \mathrm{pH} 7.3)$ or sodium acetate buffer $(50 \mathrm{mM}, \mathrm{pH}$ $4.3)$ at a concentration of $2.2 \mathrm{mg} / \mathrm{ml}(2.63 \mathrm{mM})$ and a spectrum was recorded, then the enzymes were added, the final concentrations of which were in the $0.19-0.21 \mathrm{mg} / \mathrm{ml}$ range $(0.0128$ $0.0142 \mathrm{mM}$, such enzyme concentrations are sufficient for their observation in NMR spectra). Then, the spectra were recorded until the completion of the hydrolysis process. The temperature at recording of the NMR spectra was $298 \mathrm{~K}$.

\section{Results and Discussion}

The preparation of target compound 1 involved chemical synthesis of protected tetrapeptide 4 from two peptide fragments 2 (Denoel et al. 2014) and 3 (Reid et al. 2019) followed by global deprotection and selective acylation of the amino group in the intermediate 5 with pentafluorophenyl ester of $\mathrm{N}$-acetylglucosaminyl-( $\beta 1-4)-\mathrm{N}$-acetylmuramic acid. The activated ester was prepared from the free acid 6 using bis(pentafluorophenyl) carbonate following the procedure described for esterification of the analogous saccharide (Jezek et al. 1990). Scheme of this synthesis is shown in Figure 1.

In this way, we have synthesized a glycopeptide that is N-acetylglucosaminyl- $\beta(1-4)-\mathrm{N}$ acetylmuramyl-L-alanyl- $\gamma$-D-glutamyl-L-alanyl-D-alanine (glucosaminyl muramyl tetrapeptide, GMTP) with a molecular weight of $840 \mathrm{Da}$. GMTP is a water soluble compound that simulates the glycopeptide region of the peptidoglycan of the bacterial cell wall, containing the L-Ala-DGlu dipeptide, which is hydrolyzed by the bacteriophage peptidases EndoT5, EndoRB43, and EndoRB49. The structure of GMTP is shown in Figure 2, whereas Table 1 represents the 
234

235

236

237

238

239

240

241

242

243

244

245

246

247

248

249

250

251

252

253

254

255

256

257

258

259

260

261

262

263

264

265

266

267

268

269

270

271

272

273

assignments of the NMR lines, which we obtained based on the analysis of the NMR spectra: ${ }^{1} \mathrm{H}$ ${ }^{-13} \mathrm{C}-\mathrm{HSQC},{ }^{1} \mathrm{H}-{ }^{13} \mathrm{C}-\mathrm{HMBC},{ }^{1} \mathrm{H}-{ }^{1} \mathrm{H}-\mathrm{COSY},{ }^{1} \mathrm{H}-{ }^{1} \mathrm{H}-\mathrm{TOCSY}$.

When a homogeneous recombinant enzyme preparation is added to the GMTP solution, the degradation of a substrate begins by the hydrolysis of the peptide bond between L-Ala ${ }_{1}$ and D$\mathrm{Glu}_{2}$. The cleavage of this bond is evidenced by the characteristic changes in the NMR spectra, such as: 1) the presence of the C-terminal carboxyl belonging to the residue $\mathrm{L}-\mathrm{Ala}_{1}$; 2) the absence of the signal of the amide proton of $\mathrm{D}-\mathrm{Glu}_{2} ; 3$ ) disappearance of the unique spatial environment of the $\beta_{1,2}$ - protons of the D-Glu ${ }_{2}$ residue; 4 ) significant changes in the positions of the remaining signals of the $\mathrm{L}-\mathrm{Ala}_{1}$ and D-Glu ${ }_{2}$ residues. In addition, there is a change in the chemical shift of the signal of the $\alpha$-anomeric proton of $\alpha$-N-acetylmuramic acid, as shown in Figure 3, as well as the changes in the integral intensity, which make it possible to follow the kinetics of the cleavage process, as shown in Figure 4A - 4D.

Figure $4 \mathrm{~A}$ represents kinetic curves showing a decrease in the concentration of the initial GMTP (descending), when it is cleaved by EndoRB49 peptidase at the peptide bond L-AlaD-Glu and its transformation into two products: N-acetylglucosaminyl- $\beta(1-4)-\mathrm{N}-$ acetylmuramoyl-L-alanine and $\gamma$-D-glutamyl-L-alanyl-D-alanine, the increase in the concentration of which is reflected by the rising curve. The measurements were carried out using the signals of the anomeric sugar proton at $\sim 5.4 \mathrm{ppm}$, which are shifted relative to each other and clearly distinguishable for these two products. The fitting of the experimental data was carried out by simple exponents: $f(t)=a \times e^{-\lambda \times t}$ and $f(t)=a \times\left(1-e^{-\lambda \times t}\right)$ for the ascending and descending curves, respectively (here, $\lambda$ is the decay constant). Therefore, to characterize the substrate decay rate, we used the accepted standard parameter, half-life time, defined as $t_{1 / 2}=\ln 2 / \lambda$. In the case of the EndoRB49-catalyzed GMTP hydrolysis, the $t_{1 / 2}$ value was $36 \mathrm{~min}$. Figure 4B shows the results of similar experiments for EndoT5 peptidase; i.e., where the GMTP concentration was decreasing because of its cleavage by the EndoT5 peptidase. For EndoT5 under the same conditions $1 / \lambda=49.19 \mathrm{~h}$ and $t_{1 / 2}=34.10 \mathrm{~h}$. It should be noted that the addition of a mutant EndoT5 with a point substitution of the catalytic aspartate (EndoT5D130A) to the GMTP solution did not cause substrate hydrolysis, in contrast to the wild type protein (see black circles in Figure 4B). Figure 4C shows the curves of the GMTP hydrolysis by EndoRB49 peptidase at $\mathrm{pH} 4.3$, which is outside the physiological $\mathrm{pH}$ optimum of this enzyme. In fact, the $\mathrm{pH}$ optimum for all three studied enzymes is wide and lies in the range of 7.0-9.0 (Mikoulinskaia et al. 2018; Mikoulinskaia et al. 2013). Therefore, $\mathrm{pH} 7.3$ and $\mathrm{pH} 8.0$ that were used in previous work for the analysis of catalytic reactions of EndoT5, EndoRB43, and EndoRB49 (Shadrin et al. 2020) are within this $\mathrm{pH}$ optimum range, whilst $\mathrm{pH}$ 4.3 is the value at which enzymes are practically devoid of activity. It is these $\mathrm{pH}$ values that were used for structural NMR experiments, since they provide the minimum proton exchange of peptide bonds and the maximum protein solubility, which significantly improves the quality of NMR spectra and reduces the time required to obtain a complete set of spectra for structural analysis. The very high rate of hydrolysis of GMTP by the EndoRB49 enzyme suggested that it might have residual catalytic activity even at $\mathrm{pH} 4.3$, which was in fact demonstrated. This 
274 eliminates the question of the adequacy of the conditions for obtaining the structural, dynamic 275 and catalytic characteristics, which is very important for future structural studies of the protein 276 EndoRB49, which is extremely interesting and promising in terms of biotechnological 277 applications. It is also important to emphasize that the residual activities of other investigated 278 orthologous peptidases - EndoT5 and EndoRB43 - at pH 4.3 are too low to be detected. Figure $2794 \mathrm{C}$ illustrates the fact that with a decrease in $\mathrm{pH}$ from the values optimal for the enzyme, the rate 280 of hydrolysis sharply decreases, and in this case $t_{1 / 2}=14.77 \mathrm{~h}$. Finally, Figure 4D shows the 281 curves reflecting the change in the initial GMTP concentration upon its cleavage by the 282 EndoRB43 peptidase. At a EndoRB43 concentration of $0.19 \mathrm{mg} / \mathrm{ml}, t_{1 / 2}=8.8 \mathrm{~h}$.

283 A four-fold increase in the protein concentration at a constant substrate concentration naturally 284 led to a decrease in the $t_{1 / 2}$ value. In our study, the half-life decreased from $t_{1 / 2}=8.8 \mathrm{~h}$ to $t_{1 / 2}=2.1$ $285 \mathrm{~h}$ for EndoRB43. Since the protein retains its properties under the same environmental 286 287 conditions, the coefficient $\lambda$ must remain the same, which means that the coefficient $a$ must change and depend on the concentrations of the protein and substrate. Based on our data, this means that the coefficient $a=\mathrm{C}_{\text {substrate }} / \mathrm{C}_{\text {protein }}$ almost linearly depends on the concentrations: an increase in the protein concentration leads to a decrease in $a$, and hence the half-life time $\left(t_{1 / 2}\right)$, an increase in the substrate concentration leads to an increase in $a$ and to an increase in $t_{1 / 2}$. In our study, a 4-fold decrease in the protein concentration $\left(\mathrm{C}_{\text {substrate }} / \mathrm{C}_{\text {protein }} / 4=4 \times \mathrm{C}_{\text {protein }} / \mathrm{C}_{\text {substrate }}\right)$ ) $=4 a$, led to a 4 -fold increase in the GMTP half-life.

293 Figures 5A and 5C show the ${ }^{1} \mathrm{H}-\mathrm{NMR}$ spectra of the GMTP glycopeptide in the presence of the 294 zinc-containing form of the most active enzyme, EndoRB49. The spectra of the aliphatic region show mostly GMTP signals, since the protein signals are much lower in amplitude and therefore practically are not detectable. In the ${ }^{1} \mathrm{H}-\mathrm{NOE}$ spectra upon excitation at a frequency of the protein methyl pool of $\sim 0.8 \mathrm{ppm}$ (Figure 5B and 5D), protein signals appear due to spin diffusion (Melnik et al. 2011). In addition, one can clearly see prominent responses of the GMTP alanine signals in the range of $1.45-1.25 \mathrm{ppm}$. These signals-responses appear when the excitation energy is transferred from the protein molecule when it reaches the GMTP molecule, as a result of which the hydrolysis of the L-Ala-D-Glu peptide bond occurs (Figure 5C). As the peptide transforms, these signals decrease in intensity and change their position corresponding to alanine signals in the resulting peptide without the sugar part. With the complete cleavage of GMTP molecules by the enzyme, the spectra have the form shown in Figure 5B and 5D. Therefore, the alanine part of GMTP serves as an "anchor site" defining orientation of the glycopeptide and providing its retention sufficient for the hydrolysis that is captured by a protein molecule for the rapprochement with the substrate mimetic and subsequent enzymatic reaction. The signal at $1.4 \mathrm{ppm}$ belongs to the methyl group of $\mathrm{N}$-acetylmuramic acid, and the signal at 1.44 ppm belongs to the methyl group of $\mathrm{Ala}_{1}$ (see Table 1). This means that just in this region the distance between the enzyme molecule and the glycopeptide is the smallest, which most likely indicates the position of the interaction site near the $\mathrm{N}$-acetylmuramic acid of the glycopeptide. However, the excitation energy transfer is not observed for the signals from the carbohydrate residues of the glycopeptide. Therefore, the interaction in this region is almost 
314 pointwise. This site of interaction on the glycopeptide is common to all of the enzymes analyzed

315 in this study and does not depend on the rate of the transformation reaction. The protein

316 molecule retains the affinity for the methyl part of all alanine residues after the cleavage of

317 GMTP, since the energy transfer from the protein occurs even after the end of the enzymatic

318 reaction, as can be seen in the ${ }^{1} \mathrm{H}-\mathrm{NOE}$ spectrum in Figure 5D. However, it is possible that this

319 is no longer a specific interaction, but a simple hydrophobic interaction of alanines with a protein

320 molecule.

321 It is difficult to say to what extent this interaction takes place in a natural substrate, the structure

322 of which differs significantly from an artificial glycopeptide. For example, in position 3 of the

323 peptide subunit, L-alanine is practically absent in bacteria, and in peptidoglycan of the A1 $\gamma$ type,

324

325

326

327

328

329

330

331

332

333

334

335

336

337

338

339

340

341

342

343

344

345

346

347

348

349

350

351

352

353 characteristic of the host of bacteriophages T5, RB43 and RB49 - Escherichia coli - in position 3 is meso-diaminopimelic acid [2]. It is very likely that this has a strong effect on the rate of hydrolysis of GMTP and on the process of substrate binding, taking into account the hydrophobic interaction of the reaction products with the enzyme molecule after the hydrolysis and the hindered dissociation of the enzyme-product complex. Nevertheless, as it was shown, the glycopeptide developed in this study - N-acetylglucosaminyl- $\beta(1-4)-\mathrm{N}$-acetylmuramyl-L-alanyl$\gamma$-D-glutamyl-L-alanyl-D-alanine - may well be used as one of the mimetic peptidoglycans for modeling its hydrolysis in vitro.

The highest activity of EndoRB49 towards GMTP is in good agreement with the data indicating the low selectivity of this enzyme in relation to the cell walls of bacteria with variations in the structure of peptidoglycan. Thus, it was recently shown (Shadrin et al. 2020) that this enzyme, with the highest rate among the studied enzymes, hydrolyzes the cell wall of not only Gramnegative bacteria, but also Gram-positive bacteria of the genera Bacillus, Cellulomonas and Sporosarcina, whose peptidoglycans had different structures (A1 $\gamma, \mathrm{A} 4 \alpha, \mathrm{A} 4 \beta)$ and chemical modifications (amidation). However, it is clear that to demonstrate conclusively that the enzymes differ in their selectivity toward peptidoglycan would require additional experiments performed using purified peptidoglycan or specific muropeptides (which is outside the scope of the current study).

It seems that our data suggest that the methyl groups of all 3 alanine residues can act as anchor points for protein binding. This raises an important question on the biological relevance of binding to the methyl group of the L-Ala at position 3 of the peptide stem, as this amino acid is not present in naturally occurring muropeptides. To answer this question one should remember that in naturally occurring muropeptides, a rather extended hydrophobic side chain region is always present in position 3 . This was modeled here using a pair of alanines, which made it possible to show the process of catalysis and substrate binding by the proteins under study. It should also be noted that any model that is closest to nature is nothing more than a simplification justified by certain considerations. To study the various molecular details of the catalytic process, such as substrate binding, enzyme-substrate affinity, reaction rate, processivity and selectivity of the enzyme, mimetics of various structures can be optimal, and only a comparative analysis will help uniting the results of experiments and specific problems. 
354 It would be interesting and important to know whether the disaccharide portion of the mimetic is

355

356

357

358

359

360

361

362

363

364

365

366

367

368

369

370

371

\section{Conclusions}

373

374

375

376

377

378

379

380

381

382

383

384

385

386

387

388

389

390

391

392

393

394 vitro.

\section{References} Heinemann.

required for activity. However, there is evidence that it is so. First, while the NOE spectra do not show signals from the protons of the sugar rings, which means that they are quite far from the protein globule, the protons of the methyl groups indicated in Figure 2 as "NHA" contribute to the spectrum in the range $2-1.9 \mathrm{ppm}$ (Figure 5 B), although these signals disappear at the end of the hydrolysis process. This suggests that the whole glycopeptide is oriented relative to the protein molecule in such a way that its hydrophobic groups come close to the protein surface, fixing positioning of the glycopeptide relative to protein globule by hydrophobic interactions so that the disaccharide forms a rather large angle with the protein surface. Moreover, the amino group of alanine, that would appear in the absence of an amide bond with muramic acid, is likely to inhibit with hydrolysis in the same way as did amidation of the C-terminal glutamate in GMDP (this biologically active mimetic, as we have verified, is not hydrolyzed by the studied enzymes, despite the similarity with natural PG). However, the assumption about the importance of the disaccharide part requires additional experimental support, and for the relevance of such an experiment, we are planning to use not only molecule 5, but also other relevant molecules such as shortened minimal substrates - four-membered species with different structures (disaccharide dipeptides).

In this work, one of the simplest models mimicking the peptidoglycan fragment of the bacterial cell wall, glycopeptide N-acetylglucosaminyl- $\beta(1-4)$-N-acetylmuramyl-L-alanyl- $\gamma-D-g l u t a m y l-L-$ alanyl-D-alanine, was successfully synthesized. This water soluble peptidoglycan mimetic and its in vitro degradation by the lytic L-alanoyl-D-glutamate peptidases of colibacteriophages T5, RB43, and RB49 (EndoT5, EndoRB43, and EndoRB49, respectively) were characterized by the solution NMR. It is shown that this model peptidoglycan can be hydrolized by EndoT5, EndoRB43, and EndoRB49, with the cleavage efficiency being enzyme- and environmental pHdependent. It was also shown that to hydrolyze this glycopeptide mimetic, enzymes approach the glycopeptide near the methyl groups of all three alanines. Therefore, developed in this study glycopeptide may serve as a suitable model for the analysis of the peptidoglycan hydrolysis in

Armarego WLF, and Chai C. 2012. Purification of laboratory chemicals. Oxford: Butterworth-

Bougault C, Ayala I, Vollmer W, Simorre JP, and Schanda P. 2019. Studying intact bacterial peptidoglycan by proton-detected NMR spectroscopy at 100kHz MAS frequency. $J$ Struct Biol 206:66-72. 10.1016/j.jsb.2018.07.009

Denoel T, Zervosen A, Lemaire C, Joris B, Herve M, Blanot D, Zaragoza G, and Luxen A. 2014. Enantioselective synthesis of alpha-benzylated lanthionines and related tripeptides for biological incorporation into E. coli peptidoglycan. Org Biomol Chem 12:9853-9863. $10.1039 / \mathrm{c} 4 \mathrm{ob} 01476 \mathrm{f}$

PeerJ reviewing PDF | (2020:11:55654:2:0:NEW 23 Apr 2021) 
395

396

397

398

399

400

401

402

403

404

405

406

407

408

409

410

411

412

413

414

415

416

417

418

419

420

421

422

423

424

425

426

427

428

429

430

431

432

433

434

435

436

437

438

439

Jezek E, Makarov A, Balashova TA, Budesínsky M, Andronova TM, and Ivanov VT. 1990. Synthesis of tetrasaccharide containing glycopeptides related to bacterial cell wall starting from free tetrasaccharide by the pentafluorophenyl ester method. Collect Czech Chem Comm 55:1326-1335.

Kern T, Hediger S, Muller P, Giustini C, Joris B, Bougault C, Vollmer W, and Simorre JP. 2008. Toward the characterization of peptidoglycan structure and protein-peptidoglycan interactions by solid-state NMR spectroscopy. J Am Chem Soc 130:5618-5619. 10.1021/ja7108135

Lee KO, Kong M, Kim I, Bai J, Cha S, Kim B, Ryu KS, Ryu S, and Suh JY. 2019. Structural Basis for Cell-Wall Recognition by Bacteriophage PBC5 Endolysin. Structure 27:13551365 e1354. 10.1016/j.str.2019.07.001

Maya-Martinez R, Alexander JAN, Otten CF, Ayala I, Vollmer D, Gray J, Bougault CM, Burt A, Laguri C, Fonvielle M, Arthur M, Strynadka NCJ, Vollmer W, and Simorre JP. 2018. Recognition of Peptidoglycan Fragments by the Transpeptidase PBP4 From Staphylococcus aureus. Front Microbiol 9:3223. 10.3389/fmicb.2018.03223

Medvedkin VN, Mitin Yu V, Klimenko LV, Podgornova NN, and Bystrichenko AI. 1989. [Dipentafluorophenyl carbonate--a reagent for peptide synthesis]. Bioorg Khim 15:460464.

Melnik BS, Molochkov NV, Prokhorov DA, Uversky VN, and Kutyshenko VP. 2011. Molecular mechanisms of the anomalous thermal aggregation of green fluorescent protein. Biochim Biophys Acta 1814:1930-1939. 10.1016/j.bbapap.2011.07.017

Mikoulinskaia GV, Chernyshov SV, Shavrina MS, Molochkov NV, Lysanskaya VY, and Zimin AA. 2018. Two novel thermally resistant endolysins encoded by pseudo T-even bacteriophages RB43 and RB49. J Gen Virol 99:402-415. 10.1099/jgv.0.001014

Mikoulinskaia GV, Odinokova IV, Zimin AA, and Stepnaya OA. 2013. L-alanoyl-D-glutamate peptidase (bacteriophage T5). In: Rawlings N, and Salvesen G, eds. Handbook of Proteolytic Enzymes. 3 ed: Elsevier 1411-1414.

Perez-Dorado I, Campillo NE, Monterroso B, Hesek D, Lee M, Paez JA, Garcia P, MartinezRipoll M, Garcia JL, Mobashery S, Menendez M, and Hermoso JA. 2007. Elucidation of the molecular recognition of bacterial cell wall by modular pneumococcal phage endolysin CPL-1. J Biol Chem 282:24990-24999. 10.1074/jbc.M704317200

Reid EE, Archer KE, Shizuka M, Wilhelm A, Yoder NC, Bai C, Fishkin NE, Harris L, Maloney EK, Salomon P, Hong E, Wu R, Ab O, Jin S, Lai KC, Sikka S, Chari RVJ, and Miller ML. 2019. Effect of Linker Stereochemistry on the Activity of Indolinobenzodiazepine Containing Antibody-Drug Conjugates (ADCs). ACS Med Chem Lett 10:1193-1197. 10.1021/acsmedchemlett.9b00240

Schleifer KH, and Kandler O. 1972. Peptidoglycan types of bacterial cell walls and their taxonomic implications. Bacteriol Rev 36:407-477.

Shadrin VS, Machulin AV, Dorofeeva LV, Chernyshov SV, and Mikoulinskaia GV. 2020. Lysis of cells of diverse bacteria by 1,d-peptidases of Escherichia coli bacteriophages RB43, RB49 and T5. J Appl Microbiol. 10.1111/jam.14910

Vollmer W, Blanot D, and de Pedro MA. 2008. Peptidoglycan structure and architecture. FEMS Microbiol Rev 32:149-167. 10.1111/j.1574-6976.2007.00094.x

Young R. 2014. Phage lysis: three steps, three choices, one outcome. J Microbiol 52:243-258. $10.1007 / \mathrm{s} 12275-014-4087-\mathrm{z}$

Peer] reviewing PDF | (2020:11:55654:2:0:NEW 23 Apr 2021) 


\section{$441 \quad$ Figure legends}

442

443

444

445

446

447

448

449

450

451

452

453

454

455

456

457

458

459

460

461

462

463

464

465

466

467

468

469

470

471

472

Figure 1. Scheme representing synthesis of the endolysin substrate mimetic 1. a) $\mathrm{CF}_{3} \mathrm{CO}_{2} \mathrm{Pfp}$, Py, DCM; b) 3, NMM, MeCN, $62 \%$; c) TFA, $\mathrm{H}_{2} \mathrm{O}, 92 \%$; d) (PfpO) ${ }_{2} \mathrm{CO}$, NMM, DMF; e) 5, Py.

Figure 2. Chemical structure if the $\mathrm{N}$-acetylglucosaminyl- $\beta(1-4)-\mathrm{N}$-acetylmuramyl-L-alanyl- $\gamma$-Dglutamyl-L-alanyl-D-alanine (glucosaminyl muramyl tetrapeptide, GMTP). The numbers correspond to the sequential numbers of the amino acid residues. The peptide bond subjected to hydrolysis is colored in green.

Figure 3. Stages of changes in the ${ }^{1} \mathrm{H}-\mathrm{NMR}$ spectrum of the region of absorption of the $\alpha-$ anomeric proton of $\alpha-\mathrm{N}$-acetylmuramic acid of GMTP depending on time after the addition of enzymes. A. Spectrum taken immediately after the addition of any of the studied peptidases. B. ${ }^{1} \mathrm{H}-\mathrm{NMR}$ spectrum corresponding to the time sufficient for the conversion of $50 \%$ of the initial GMPT into N-acetylglucosamine-N-acetylmuramyl-L-alanine. C. Spectrum corresponds to the time of almost complete transformation of the initial GMPT to N-acetylglucosamine-Nacetylmuramyl-L-alanine.

Figure 4. Transformation of GMTP with the addition of enzymes. The ascending curve shows an increase in the concentration of the final product, and the descending curve shows the change in the concentration of the original substrate. The circles are the measured values, the lines are the exponential approximations (fitting) $\left(\mathrm{R}^{2}=0.9995\right)$. In these experiments, the GMTP hydrolysis was catalyzed by A. EndoRB49 $(\mathrm{pH}=7.3)$; B. EndoT5 $(\mathrm{pH}=7.3)$. Black, filled circles show to the lack of activity of an inactivated mutant EndoT5 with the point substitution of the catalytic aspartate (EndoT5D130A); C. EndoRB49 (pH 4.3); and D. EndoRB43 (pH = 7.3).

Figure 5. ${ }^{1} \mathrm{H}-\mathrm{NMR}$ and ${ }^{1} \mathrm{H}-\mathrm{NOE}$ spectra of the aliphatic region of the EndoRB49 enzyme upon interaction with GMTP in $\mathrm{D}_{2} \mathrm{O}, \mathrm{pH} 4.2, \mathrm{~T}=295 \mathrm{~K}$. A. ${ }^{1} \mathrm{H}-\mathrm{NMR}$ (beginning of transformation); $\mathbf{B}$. ${ }^{1} \mathrm{H}-\mathrm{NOE}$ at saturation of the signal of the methyl pool of the enzyme $(\sim 0.8 \mathrm{ppm})$ (beginning of transformation); C. ${ }^{1} \mathrm{H}-\mathrm{NMR}$ (end of transformation); D. ${ }^{1} \mathrm{H}-\mathrm{NOE}$ at saturation of the signal of the methyl pool of the enzyme ( $\sim 0.8 \mathrm{ppm})$ (end of transformation). 


\section{Table 1 (on next page)}

Table 1. Signal assignment for $\mathrm{N}$-acetylglucosamine- $\beta(1-4)-\mathrm{N}$ acetylmuramyltetrapeptide. 
1 Table 1. Signal assignment for $\mathrm{N}$-acetylglucosamine- $\beta(1-4)-\mathrm{N}$-acetylmuramyltetrapeptide.

2

\begin{tabular}{|c|c|c|c|}
\hline Spin system & Atom name & $\begin{array}{l}\text { Chemical shift } \\
{ }^{1} \mathrm{H}(\mathrm{ppm})\end{array}$ & $\begin{array}{l}\text { Chemical shift } \\
{ }^{13} \mathrm{C}(\mathrm{ppm})\end{array}$ \\
\hline \multirow{9}{*}{$\beta$-N-acetylglucosamine } & $1^{\prime} \mathrm{H} ; 1^{\prime} \mathrm{C}$ & 4.544 & 102.987 \\
\hline & $2^{\prime} \mathrm{H} ; 2^{\prime} \mathrm{C}$ & 3.750 & 58.803 \\
\hline & $3^{\prime} \mathrm{H} ; 3^{\prime} \mathrm{C}$ & 3.431 & 73.035 \\
\hline & $4^{\prime} \mathrm{H} ; 4^{\prime} \mathrm{C}$ & 3.567 & 76.352 \\
\hline & $5^{\prime} \mathrm{H} ; 5^{\prime} \mathrm{C}$ & 3.434 & 78.804 \\
\hline & $6^{\prime} \mathrm{H} ; 6^{\prime} \mathrm{C}$ & 3.775 & 63.923 \\
\hline & $\mathrm{HN}_{\mathrm{Ac}}$ & 8.410 & \\
\hline & ${ }^{\prime} \mathrm{C}(\mathrm{C}=\mathrm{O})_{\mathrm{Ac}}$ & & 177.519 \\
\hline & $\mathrm{H} ; \mathrm{C}\left(\mathrm{CH}_{3}\right)_{\mathrm{Ac}}$ & 2.055 & 24.888 \\
\hline \multirow{12}{*}{$\alpha-\mathrm{N}$-acetylmuramic acid } & $1^{\prime} \mathrm{H} ; 1^{\prime} \mathrm{C}$ & 5.222 & 92.903 \\
\hline & $2^{\prime} \mathrm{H} ; 2^{\prime} \mathrm{C}$ & 3.832 & 56.352 \\
\hline & $3^{\prime} \mathrm{H} ; 3^{\prime} \mathrm{C}$ & 3.878 & 73.683 \\
\hline & $4^{\prime} \mathrm{H} ; 4^{\prime} \mathrm{C}$ & 3.770 & 79.064 \\
\hline & $5^{\prime} \mathrm{H} ; 5^{\prime} \mathrm{C}$ & 3.873 & 78.102 \\
\hline & $6^{\prime} \mathrm{H} ; 6^{\prime} \mathrm{C}$ & 3.826 & 62.548 \\
\hline & $\mathrm{HN}_{\mathrm{Ac}}$ & 7.906 & \\
\hline & ${ }^{\prime} \mathrm{C}(\mathrm{C}=\mathrm{O})_{\mathrm{Ac}}$ & & 176.847 \\
\hline & $\mathrm{H} ; \mathrm{C}\left(\mathrm{CH}_{3}\right)_{\mathrm{Ac}}$ & 1.950 & 24.842 \\
\hline & $\mathrm{H} ; \mathrm{C}(\mathrm{CH})_{\mathrm{Lac}}{ }^{\mathrm{a}}$ & 4.544 & 80.359 \\
\hline & $\mathrm{H} ; \mathrm{C}\left(\mathrm{CH}_{3}\right)_{\mathrm{Lac}^{\mathrm{a}}}$ & 1.404 & 20.769 \\
\hline & ${ }^{\prime} \mathrm{C}(\mathrm{C}=\mathrm{O})_{\mathrm{Lac}^{\mathrm{a}}}$ & & 177.993 \\
\hline \multirow{12}{*}{$\beta$-N-acetylmuramic acid } & $1^{\prime} \mathrm{H} ; 1^{\prime} \mathrm{C}$ & 4.648 & 97.778 \\
\hline & $2^{\prime} \mathrm{H} ; 2^{\prime} \mathrm{C}$ & 3.720 & 58.399 \\
\hline & $3^{\prime} \mathrm{H} ; 3^{\prime} \mathrm{C}$ & 3.857 & 78.105 \\
\hline & $4^{\prime} \mathrm{H} ; 4^{\prime} \mathrm{C}$ & 3.599 & 81.948 \\
\hline & $5^{\prime} \mathrm{H} ; 5^{\prime} \mathrm{C}$ & 3.482 & 77.834 \\
\hline & $6^{\prime} \mathrm{H} ; 6^{\prime} \mathrm{C}$ & 3.886 & 62.604 \\
\hline & $\mathrm{HN}_{\mathrm{Ac}}$ & 7.706 & \\
\hline & ${ }^{\prime} \mathrm{C}(\mathrm{C}=\mathrm{O})_{\mathrm{Ac}}$ & & 176.958 \\
\hline & $\mathrm{H} ; \mathrm{C}\left(\mathrm{CH}_{3}\right)_{\mathrm{Ac}}$ & 1.977 & 24.842 \\
\hline & $\mathrm{H} ; \mathrm{C}(\mathrm{CH})_{\mathrm{Lac}^{\mathrm{a}}}$ & 4.544 & 80.359 \\
\hline & $\mathrm{H} ; \mathrm{C}\left(\mathrm{CH}_{3}\right)_{\mathrm{Lac}^{\mathrm{a}}}^{\mathrm{a}}$ & 1.404 & 20.769 \\
\hline & 'C $(\mathrm{C}=\mathrm{O})_{\mathrm{Lac}^{\mathrm{a}}}^{\mathrm{a}}$ & & 177.993 \\
\hline \multirow[b]{2}{*}{ L-Ala ${ }_{1}$} & $\mathrm{HN}$ & 8.433 & \\
\hline & $\alpha \mathrm{H} ; \alpha \mathrm{C}$ & 4.329 & 52.685 \\
\hline
\end{tabular}




\begin{tabular}{|c|c|c|c|}
\hline & $\beta \mathrm{H} ; \beta \mathrm{C}$ & 1.442 & 19.737 \\
\hline & ${ }^{\prime} \mathrm{C}(\mathrm{C}=\mathrm{O})$ & & 176.735 \\
\hline \multirow{6}{*}{ D-Glu 2} & $\mathrm{HN}$ & 8.027 & \\
\hline & $\alpha \mathrm{H} ; \alpha \mathrm{C}$ & 4.276 & 57.120 \\
\hline & $\beta \mathrm{H}_{1,2} ; \beta \mathrm{C}$ & $1.935 ; 2.125$ & 30.912 \\
\hline & $\gamma \mathrm{H}_{1,2} ; \gamma \mathrm{C}$ & 2.326 & 34.658 \\
\hline & ${ }^{\prime} \mathrm{C}(\mathrm{C}=\mathrm{O})_{\mathrm{B}-\mathrm{b}}$ & & 176.775 \\
\hline & ${ }^{\prime} \mathrm{C}(\mathrm{C}=\mathrm{O})_{\mathrm{S}-\mathrm{ch}}$ & & 178.503 \\
\hline \multirow{4}{*}{ L-Ala 3} & $\mathrm{HN}$ & 8.238 & \\
\hline & $\alpha \mathrm{H} ; \alpha \mathrm{C}$ & 4.279 & 52.702 \\
\hline & $\beta \mathrm{H} ; \beta \mathrm{C}$ & 1.378 & 19.579 \\
\hline & ${ }^{\prime} \mathrm{C}(\mathrm{C}=\mathrm{O})$ & & 176.776 \\
\hline \multirow{4}{*}{ D-Ala 4} & $\mathrm{HN}$ & 7.878 & \\
\hline & $\alpha \mathrm{H} ; \alpha \mathrm{C}$ & 4.156 & 53.648 \\
\hline & $\beta \mathrm{H} ; \beta \mathrm{C}$ & 1.315 & 20.270 \\
\hline & ${ }^{\prime} \mathrm{C}(\mathrm{C}=\mathrm{O})$ & & 182.413 \\
\hline
\end{tabular}

3

4

5

6 a The chemical shifts for lactate nuclei are indistinguishable for $\alpha$ - and $\beta$-isomers of $\mathrm{N}$ -

7 acetylmuramic acid;

$8{ }^{b}$ Green font is used to indicate the positions of the signals from the hydrolyzed bond highlighted 9 in green in Figure 2. 
Figure 1

Figure 1. Scheme representing synthesis of the endolysin substrate mimetic 1.

a) CF3CO2Pfp, Py, DCM; b) 3, NMM, MeCN, $62 \%$; c) TFA, H2O, $92 \%$; d) (PfpO) ${ }_{2} \mathrm{CO}, \mathrm{NMM}$, DMF; e) 5, Py.<smiles>CCCCC(C)C(=O)NC(CCC(=O)O)C(=O)NC(C)C(=O)OC(C)(C)C</smiles><smiles>CCCCC(=O)OC(C)C(=O)NC(C)C(C)N</smiles>

3<smiles>[Y]NC(C)C(=O)NC(CCC(=O)NC(C)C(=O)NC(C)C(=O)O)C(=O)O[R]</smiles>

4: $X=B o c, R={ }^{t} B u$

$c$

5: $\mathrm{X}=\mathrm{H}\left(x \mathrm{CF}_{3} \mathrm{CO}_{2} \mathrm{H}\right), \mathrm{R}=\mathrm{H}$

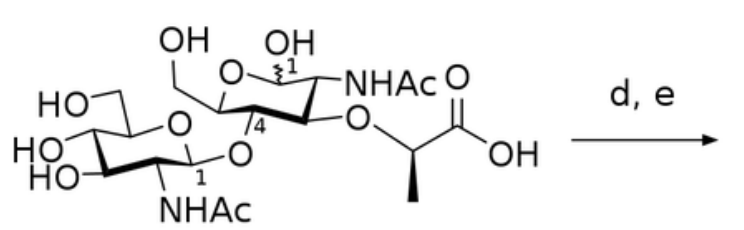

6

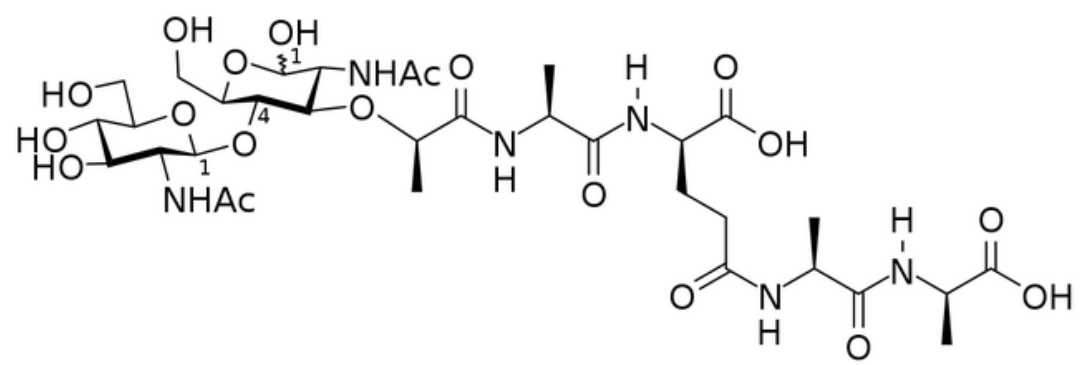

1 
Figure 2

Chemical structure if the $\mathrm{N}$-acetylglucosaminyl- $\beta(1-4)-\mathrm{N}$-acetylmuramyl-I-alanyl- $\gamma-\mathrm{d}$ glutamyl-I-alanyl-d-alanine (glucosaminyl muramyl tetrapeptide, GMTP).

The numbers correspond to the sequential numbers of the amino acid residues. The peptide bond subjected to hydrolysis is colored in green.

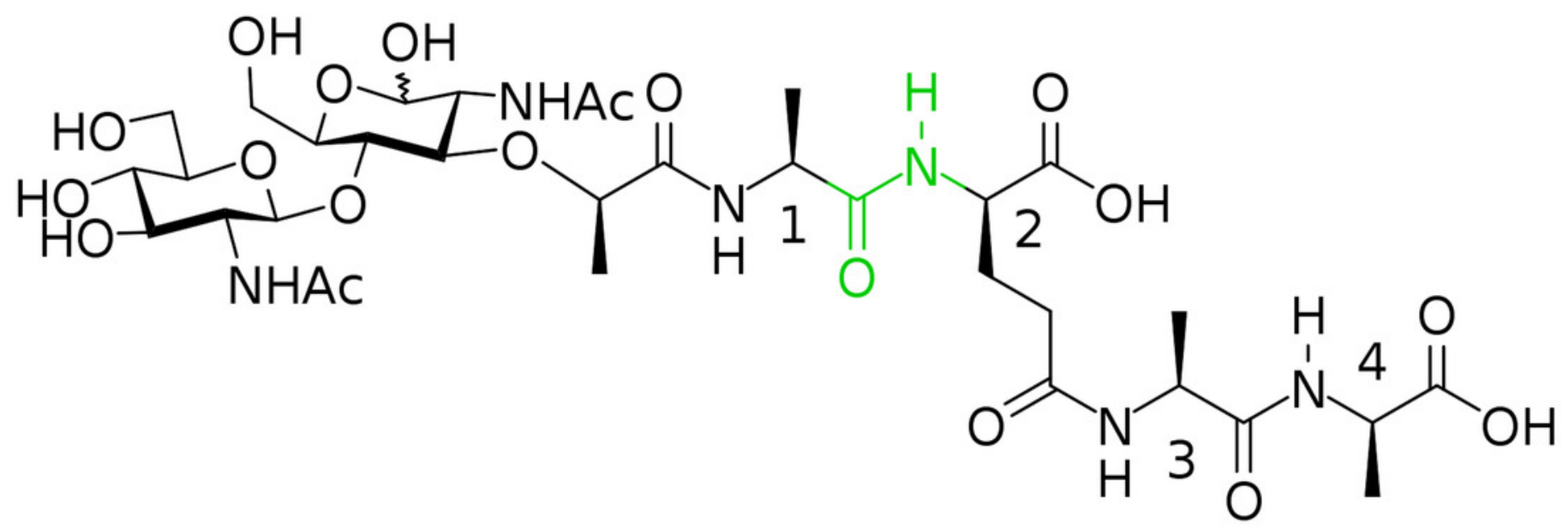


Figure 3

Stages of changes in the ${ }^{1} \mathrm{H}$-NMR spectrum of the region of absorption of the $\alpha$-anomeric proton of $\alpha$-N-acetylmuramic acid of GMTP depending on time after the addition of enzymes.

A. Spectrum taken immediately after the addition of any of the studied peptidases. B. ${ }^{1} \mathrm{H}$ NMR spectrum corresponding to the time sufficient for the conversion of $50 \%$ of the initial GMPT into N-acetylglucosamine-N-acetylmuramyl-I-alanine. C. Spectrum corresponds to the time of almost complete transformation of the initial GMPT to N-acetylglucosamine-Nacetylmuramyl-I-alanine.
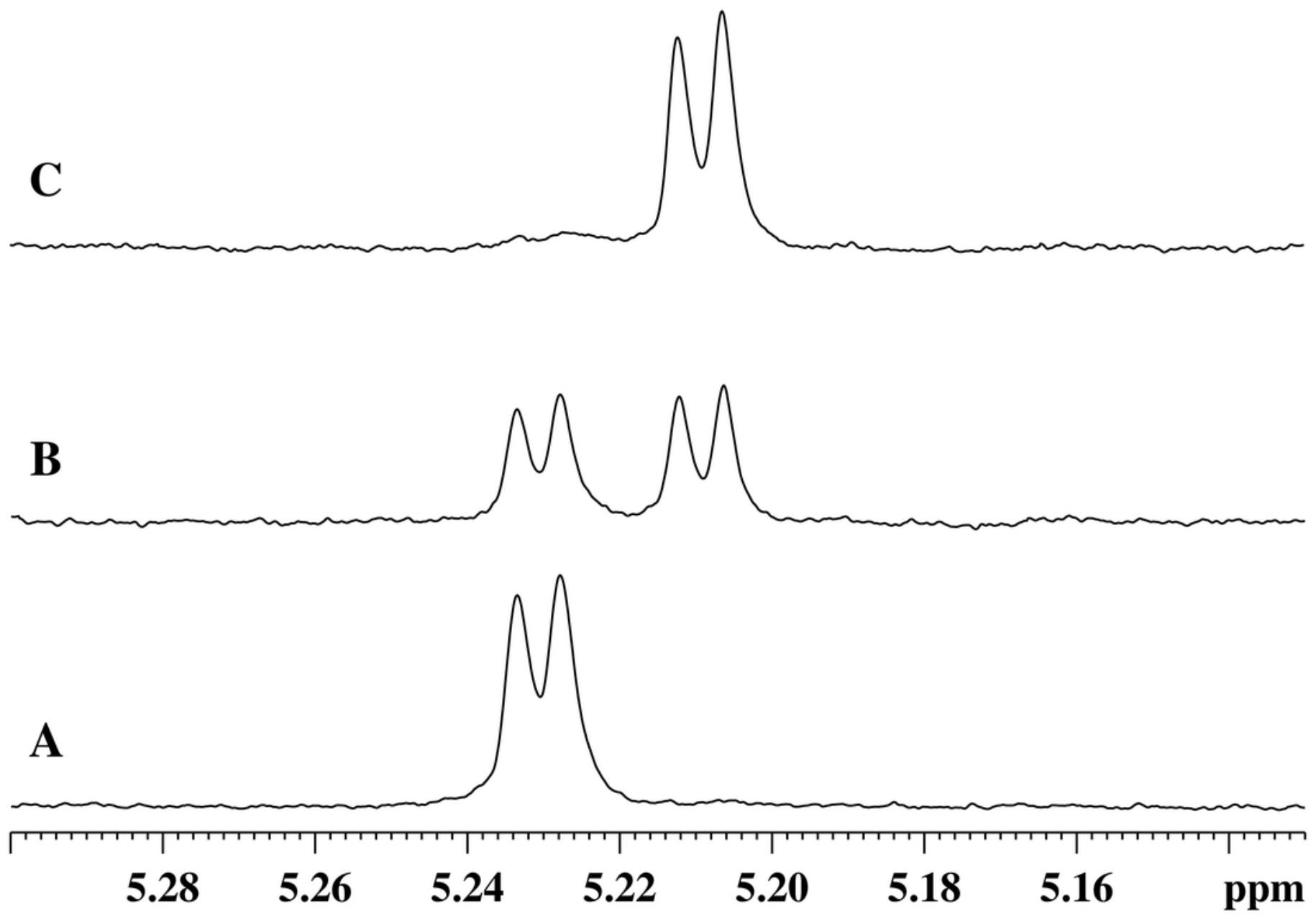
Figure 4

Transformation of GMTP with the addition of enzymes.

The ascending curve shows an increase in the concentration of the final product, and the descending curve shows the change in the concentration of the original substrate. The circles are the measured values, the lines are the exponential approximations (fitting) $\left(R^{2}=0.9995\right)$. In these experiments, the GMTP hydrolysis was catalyzed by A. EndoRB49 $(\mathrm{pH}=7.3)$; $\mathbf{B}$. EndoT5 ( $\mathrm{pH}=7.3$ ). Black circles show to the lack of activity of an inactivated mutant EndoT5 with the point substitution of the catalytic aspartate (EndoT5D130A); C. EndoRB49 (pH 4.3); and D. EndoRB43 (pH = 7.3).
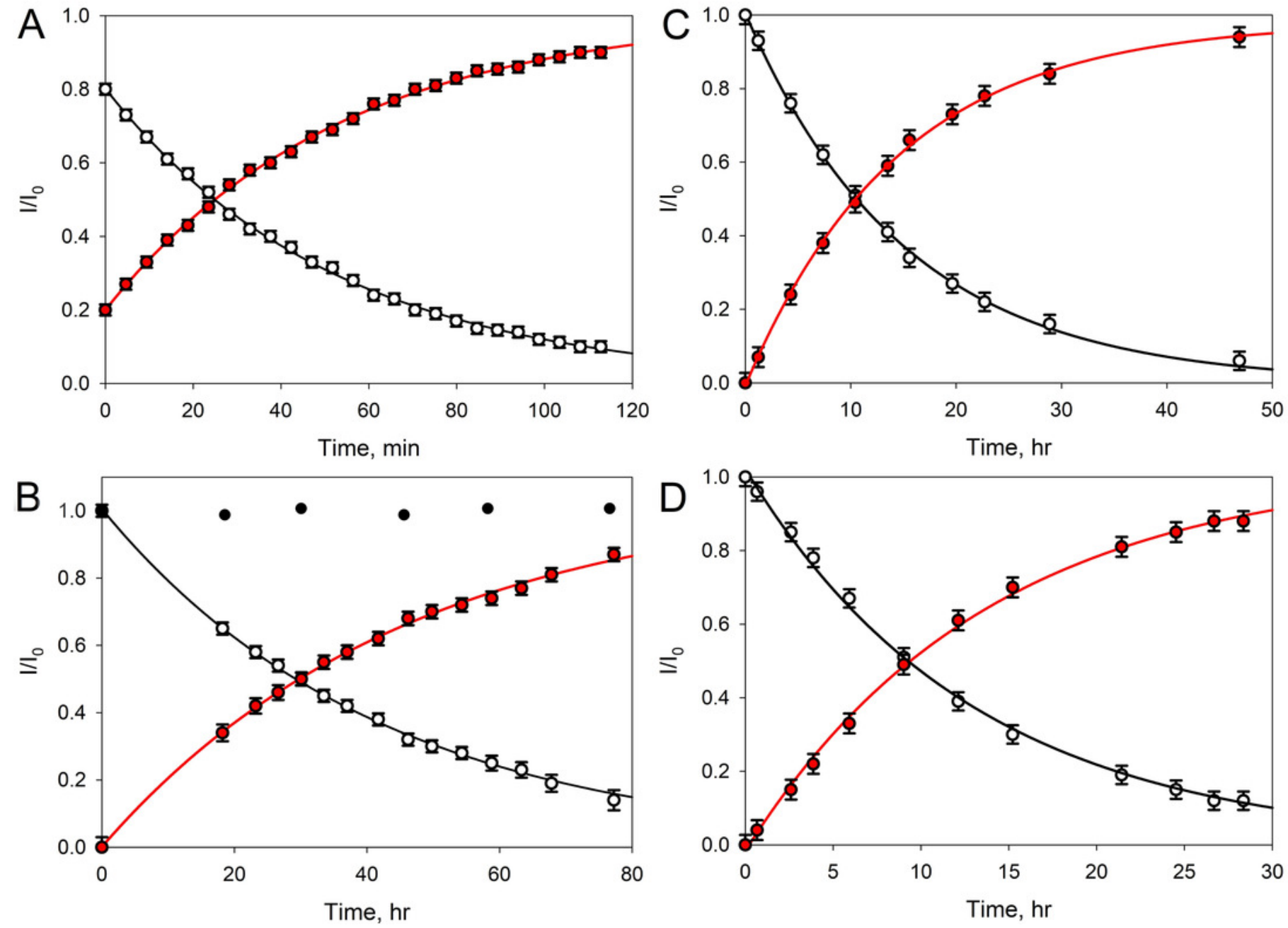
Figure 5

${ }^{1} \mathrm{H}$-NMR and ${ }^{1} \mathrm{H}-\mathrm{NOE}$ spectra of the aliphatic region of the EndoRB49 enzyme upon interaction with GMTP in $\mathrm{D}_{2} \mathrm{O}, \mathrm{pH} 4.2, \mathrm{~T}=295 \mathrm{~K}$.

A. ${ }^{1} \mathrm{H}-\mathrm{NMR}$ (beginning of transformation); B. ${ }^{1} \mathrm{H}-\mathrm{NOE}$ at saturation of the signal of the methyl pool of the enzyme ( $0.8 \mathrm{ppm}$ ) (beginning of transformation); C. ${ }^{1} \mathrm{H}-\mathrm{NMR}$ (end of transformation); D. ${ }^{1} \mathrm{H}-\mathrm{NOE}$ at saturation of the signal of the methyl pool of the enzyme ( $0.8 \mathrm{ppm}$ ) (end of transformation)
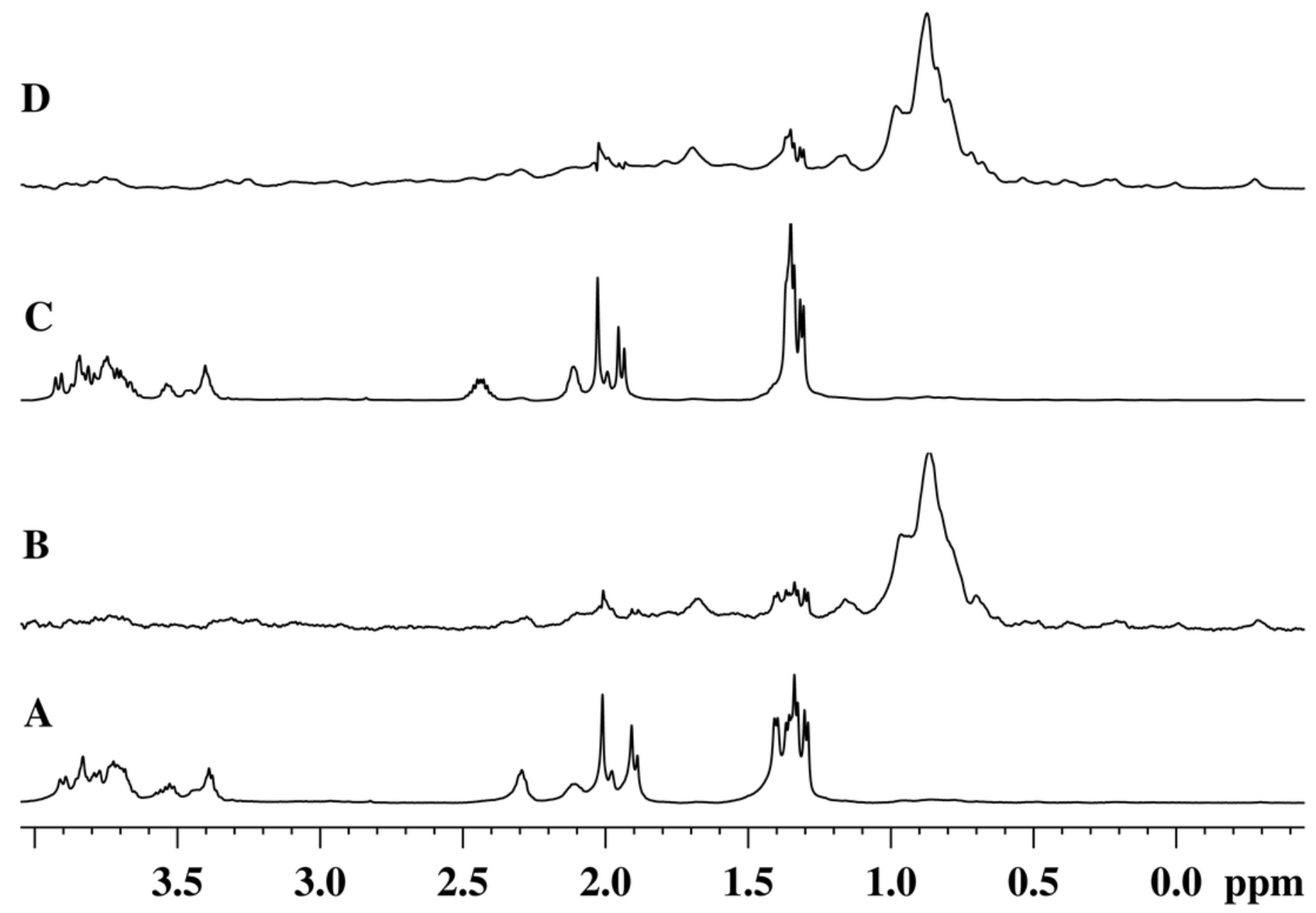